\title{
Zoonotic bacterial survey assessed by next-generation sequencing
}

\author{
M Razzauti ${ }^{*}$, M Galan ${ }^{1}$, M Bernard ${ }^{2}$, J Cheval ${ }^{3}$, S Maman $^{4}$, N Charbonnel ${ }^{1}$, M Vayssier-Taussat ${ }^{5}$, M Eloit ${ }^{3,6,7}$, J-F Cosson ${ }^{1}$ \\ From The 1st Conference on Neglected Vectors and Vector-Borne Diseases (EurNegVec): with Management \\ Committee and Working Group Meetings of the COST Action TD1303 \\ Cluj-Napoca, Romania. 8-11 April 2014
}

Rodents represent one of the major sources of pathogens; most of them are vectored by ticks. Tick-borne diseases are very diverse and cause a wide range of diseases in livestock and human populations. Rodents, carrying ticks, are distributed across a vast range of natural habitats and they often live in close contact with humans and their domestic animals, exposing them to zoonoses circulating in natural ecosystems. In this study, we analyse the potential of Next-Generation Sequencing (NGS) technologies as a tool for large-scale survey of bacterial zoonotic pathogens carried by rodents. We combined two NGS approaches in order to establish a list of zoonotic bacteria and to identify their distribution in individuals of rodents in natural populations.

Briefly, RNA/DNA were extracted from the spleen of 192 rodents collected in Northeast France. RNA from all samples was pooled and submitted to high throughput RNA sequencing (RNAseq). Succeeding de novo assembly, bacterial contigs were assigned to the closest already-known taxa, revealing a list of zoonotic bacteria for the whole sample. Parallel, DNA samples were submitted to meta-barcoding approach: each sample was amplified by PCR using universal primers tagged at the $\mathrm{V} 4$ region of the $16 \mathrm{~S}$ rRNA. The amplified templates were multiplexed and submitted to 454-pyrosequencing. The resulting dataset was demultiplexed using a home-made pipeline that assigns each read to a sample using the tagged primers, following these were processed using Mothur pipeline to construct OTUs and classify them using the RDP database. These methods allowed listing bacteria detected in each rodent and, so derive the prevalence, coinfections and bacteria interactions.

* Correspondence: maria.razzauti@supagro.inra.fr

'INRA, UMR CBGP (INRA / IRD / Cirad / Montpellier SupAgro), France

Full list of author information is available at the end of the article
DNA/RNA of the following bacteria genera were detected by both approaches, RNAseq and DNA 16S-metabarcoding: Bartonella, Leptospira, Borrelia, Rickettsia, Treponema, Neisseria, Spiroplasma, Klebsiella, Listeria and Shigella. Some unexpected genera were detected; such as Orientia, up to now only found in Asia or Helicobacter, generally thought to be restricted to animal guts. Several bacterial pathogens explored by RNAseq passed undetected by 16S-metabarcoding: Anaplasma, (Neo)Ehrlichia, Wolbachia, Brucella, Coxiella, Campylobacter, Mycoplasma, Salmonella, Yersinia, and Francisella. Furthermore, $16 \mathrm{~S}$ meta-barcoding allowed to specify prevalence of bacteria within our sample, and revealed high level of coinfection in wild rodents.

Our data demonstrate that NGS allows having a rather complete screening of pathogenic bacteria present in animal reservoirs without any a priori on their presence, while having a price compatible with cohort studies. NGS approaches are becoming the new routine approaches in large-scale epidemiological studies.

\begin{abstract}
Authors' details
${ }^{1}$ INRA, UMR CBGP (INRA / IRD / Cirad / Montpellier SupAgro), France. ${ }^{2}$ INRA, GABI, Sigenae, Domaine de Vilvert, 78352 Jouy-en-Josas, France. ${ }^{3}$ PathoQuest SAS, Paris, France. ${ }^{4}$ INRA, LGC, Sigenae, Chemin de Borde rouge 31326

Castanet Tolosan, France. ${ }^{5}$ INRA, UMR Bipar, Enva, Anses, USC INRA, MaisonsAlfort, France. ${ }^{6}$ Ecole Nationale Vétérinaire d'Alfort, UMR 1161 Virologie ENVA, INRA, ANSES, Maisons-Alfort, France. ${ }^{7}$ Institut Pasteur, Laboratory of Pathogen Discovery, Paris, France.
\end{abstract}

Published: 1 April 2014

doi:10.1186/1756-3305-7-S1-014

Cite this article as: Razzauti et al: Zoonotic bacterial survey assessed by next-generation sequencing. Parasites \& Vectors 2014 7(Suppl 1):O14.
C Biomed Central

(C) 2014 Razzauti et al.; licensee BioMed Central Ltd. This is an Open Access article distributed under the terms of the Creative Commons Attribution License (http://creativecommons.org/licenses/by/4.0), which permits unrestricted use, distribution, and reproduction in any medium, provided the original work is properly cited. The Creative Commons Public Domain Dedication waiver (http://creativecommons.org/publicdomain/zero/1.0/) applies to the data made available in this article, unless otherwise stated. 